\title{
Biodiesel deposit characterization on hot chamber test rig with biodiesel fuels (B20) and bioaditif essential oil (atsiri)
}

\author{
Muchammad Taufiq Suryantoro ${ }^{1,}$, Bambang Sugiarto ${ }^{2}$, Hari Setiapraja ${ }^{1}$, Siti Yubaidah ${ }^{1}$, Ary Budi Mulyono ${ }^{2}$, \\ Mochammad Ilham Attharik ${ }^{2}$, Muhamad Raihan Ariestiawan ${ }^{2}$, and Andro Cohen ${ }^{2}$ \\ ${ }^{1}$ BT2MP-BPPT, Area Puspiptek, Serpong, Muncul, Setu, South Tangerang, Banten 15310, Indonesia \\ ${ }^{2}$ Departement of Mechanical Engineering, University of Indonesia, 16424, Indonesia
}

\begin{abstract}
In this study, the deposit formation of B20-NA biodiesel with the addition of bioadditive Essential Oil with different variations, B20 + Essential Oil 1:2000, B20 + Essential Oil 1:3000, B20 + Essential Oil 1: 4000 and B20 + Essential Oil 1:5000 method of hot plate drops to know the characteristics and mechanisms of deposit formation on each variation of fuel. The research is carried out by the deposition process and evaporation of Diesel fuels carried out repeatedly on a hot plate. The plate is heated with temperature variations inside the enclosed space so that the conditions are close to the real conditions of the engine. This test uses a hot chamber test rig. The use of bioadditive essential oils (atsiri) which have turpentine contents bind water content and residues in biodiesel fuel is expected to accelerate the process of excessive deposit release in the combustion chamber. This study aims to find the optimum fuel and temperature variations so that the deposit release process can be accelerated.
\end{abstract}

\section{Introduction}

Indonesia and several tropical countries produce a lot of energy sources including palm oil, coconut, nyamplung, rubber seeds, kosambi and various other plants. The source can be converted into biodiesel or bioethanol. This is reinforced by Regulation of The Minister of Energy and Mineral Resources, the government issued Indonesia's National Energy Policy under Regulation of The Minister of Energy and Mineral Resources of The R.I. No. 12/2015. This regulation formalized the promotion of biofuels in Indonesia, for both ethanol and biodiesel, and established a $30 \%$ biofuel in national energy consumption mandate by 2025 [1].

Nevertheless, the use of biodiesel with a greater percentage for applications in diesel engines still leaves some problems related to the occurrence of biodiesel degradation and the formation of deposits when used as fuel on the engine. Since rolling out the use of biodiesel fuel in engines, there has been an increase in reporting on the formation of deposits in both the combustion chamber and the injectors [2-4]. To date, studies on the mechanism of formation of biodiesel deposits are still small $[3,5,6]$. The ease of biodiesel for degradation is one of the factors that allegedly increases the formation of biodiesel deposits [3]. The addition of bioaddives resulting in a decrease in the viscosity price allows for higher quality of combustion resulting in faster and more complete combustion [7], but the bioadditive effect on deposit formation has not been widely reported. The formation of deposits on machines is a fairly complex phenomenon and is heavily dependent on combinations of various parameters such as fuel, material surfaces, temperature, pressure, combustion conditions, and others [8].

To address this challenge, further studies and comprehensive research activities with a focus on fuels characteristics and their deposit formation capability in different engine parts are strongly required. It is worth quoting that research on deposit formation in injector and combustion chamber basically includes measuring the thickness of the deposits in the engine componentd in response to the application of test and reference fuels [9$11]$.

\section{System Description}

\subsection{Hot Chamber Deposition Test Rig}

To obtain the appropriate deposit sample with the test fuel was tested using hot chamber method and different temperature plate. Each fuel sample is tested under the same conditions.

This test rig is designed to test both droplets and spray of injectors. For droplet test, the droplet of fuel is dropped on the heat plate cooled in accordance with the temperature of the engine plate/component, while the room temperature is assumed to be the temperature of the combustion chamber. The temperature of the combustion chamber is varied according to the temperature of the combustion chamber.

\footnotetext{
* Corresponding author: muchammad.taufiq@bppt.go.id
} 


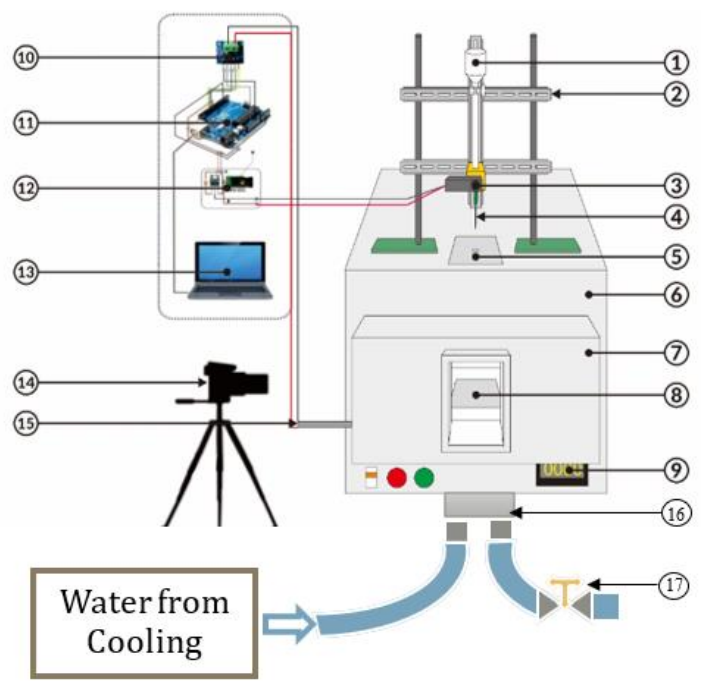

Fig. 1. Hot Chamber Deposition Test Rig.

Table 1. Caption of Hot Chamber Deposition Test Rig method.

\begin{tabular}{|c|c|}
\hline Number & Caption of Hot Chamber Deposition Test Rig \\
\hline 1 & Fuel tank / container \\
\hline 2 & Buffer fuel container \\
\hline 3 & Solenoid Valve Shako PU220AR02-24V \\
\hline 4 & Needle \\
\hline 5 & The droplet entry holes into the furnace \\
\hline 6 & Furnace with heater capacity up to $1200^{\circ} \mathrm{C}$ \\
\hline 7 & Furnace door \\
\hline 8 & Drop plate / heat plate (AISI 304) \\
\hline 9 & Furnace temperature control \\
\hline 10 & K type thermocouple module (Max6675) \\
\hline 11 & Arduino Uno R3 Microcontroller \\
\hline 12 & Power Supply 24 V DC \& Relay Solenoid \\
\hline 13 & $\begin{array}{l}\text { Laptop, temperature data display \& microcontroller } \\
\text { programming }\end{array}$ \\
\hline 14 & Video camera \\
\hline 15 & K type thermocouple \\
\hline 16 & Heat exchanger \\
\hline 17 & Manual valve \\
\hline
\end{tabular}

Research on the formation of deposits in the use of biodeisel as alternative fuel is planned for 1 year. The formation of $\mathrm{Pm} /$ soot and Nox emissions is very important to be used as material for analysis of research results. Research in this time period will present the influence of chemical structure, biodiesel to the deposit formation

\subsection{Fuel Testing}

\subsubsection{Evaporation process (Single droplet)}

The evaporation process begins with setting the Hot Chamber Deposition Test, then set the temperature for the first temperature of $250^{\circ} \mathrm{C}$. Drop plates are inserted into the furnace and sprayed with fuel once. The evaporation process is recorded using a video camera and the evaporation time is calculated from the video that has been taken. Testing is done up to $350^{\circ} \mathrm{C}$ and repeated with fuel variations.

\subsubsection{Deposition process (Multi Droplet)}

The deposition process begins with the adjustment of the Hot Chamber Deposition Test Rig test device, then performs a mass measurement for the drop plate. Set the Hot Chamber Deposition Test Rig to the temperature per 2,000 first drop and then the drop plate is inserted into the combustion chamber and depleted with fuel. After 2,000 the first drop, the drop plate is removed and the mass measured again to obtain the mass of the deposit. Testing is done until the droplets reach 10,000 and repeated with temperature variations.

\subsubsection{Bioadditives essential oil}

Additives added to the fuel serve to enrich the oxygen content in the fuel. With that, the fuel combustion efficiency can be increased and pollution can be reduced.

Essential oils are processed products derived from nature that can be used as bioaddives for fuels used in Diesel engines. Some examples of essential oils in Indonesia are clove oil, turpentine oil, nutmeg oil, gandapura oil, seren oil and eucalyptus oil. Essential oils have the potential to be used as bio-fuels for diesel engines because of a review of the structure of their constituent compounds, these materials have cyclic chains and considerable oxygen supply.

For this research, used additives mixture made from essential oils named Krastoff additives. For the mixture contained in the additive can not be known because it is still a privacy for manufacturers.

\section{Result and discussion}

In this research, there are biodiesel fuel (B20) as research reference (existing fuel) and variation of biodiesel mixture (B20) with bioaditives essential oil (atsiri). Here is a list of biodiesel samples.

In this time deposition study of fuel, used some fuel as a test sample. The fuel used as a baseline is biodiesel fuel with a mixture of $20 \%$ or B-20. Then, after collecting B-20 data, there is also data collection from B20 sample mixed with volatile oil-based bioadditive with mixture of 1: 2000, 1: 3000, 1: 4000, 1: 5000. In the 
bioadditive used, there is a mixture of several types of essential oils used commonly of Turpentine and Oxygenates, namely CSO, Eugenol, Eugenol Acetate, Limonen, Clove Terpen, Citronella and Alpha Pinen.

Table 2. Variations of biodiesel fuel and its treatment.

\begin{tabular}{|c|c|c|}
\hline Biodiesel & Bioaditif & Explanation \\
\hline B20-NA & - & $\begin{array}{c}\text { Without a mixture of } \\
\text { bioadditive essential oil } \\
\text { (reference fuel). }\end{array}$ \\
\hline $\begin{array}{c}\text { B20+ } \\
\text { Essential Oil }\end{array}$ & $\begin{array}{c}\text { Essential Oil } \\
1: 2000\end{array}$ & $\begin{array}{c}\text { Bioadditive essential oil mixed } \\
\text { with biodiesel (B20) with the } \\
\text { composition of 1: 2000. }\end{array}$ \\
\hline $\begin{array}{c}\text { B20 + } \\
\text { Essential Oil }\end{array}$ & $\begin{array}{c}\text { Essential Oil } \\
1: 3000\end{array}$ & $\begin{array}{c}\text { Bioadditive essential oil mixed } \\
\text { with biodiesel (B20) with the } \\
\text { composition of 1: 3000. }\end{array}$ \\
\hline $\begin{array}{c}\text { Essential Oil } \\
\text { B20 + }\end{array}$ & $\begin{array}{c}\text { Essential Oil } \\
1: 4000\end{array}$ & $\begin{array}{c}\text { Bioadditive essential oil mixed } \\
\text { with biodiesel (B20) with the } \\
\text { composition of 1: 4000. }\end{array}$ \\
\hline Essential Oil & $1: 5000$ & $\begin{array}{c}\text { Bioadditive essential oil mixed } \\
\text { with biodiesel (B20) with the } \\
\text { composition of 1: 5000. }\end{array}$ \\
\hline
\end{tabular}

\subsection{Hot Chamber Deposition Test Rig Condition}

The arrangement on the test rig is made in such a way as to represent conditions as in the real engine, including the room temperature in the test rig that resembles the temperature of the combustion chamber in the real engine and the temperature of the plate representing the temperature at certain places within the real engine. This can be seen in table 3 .

Table 3. Single droplet yield data (evaporation).

\begin{tabular}{|c|c|c|}
\hline $\begin{array}{c}\text { Room } \\
\text { Temperature } \\
\left({ }^{\circ} \mathbf{C}\right)\end{array}$ & $\begin{array}{c}\text { Plate } \\
\text { Temperature } \\
\left({ }^{\circ} \mathbf{C}\right)\end{array}$ & $\begin{array}{c}\text { Heat Exchanger } \\
\text { Temperature }\left({ }^{\circ} \mathbf{C}\right)\end{array}$ \\
\hline \multirow{4}{*}{450} & 250 & 227 \\
\cline { 2 - 3 } & 300 & 280 \\
\cline { 2 - 3 } & 350 & 336 \\
\hline \multirow{3}{*}{500} & 250 & 217 \\
\cline { 2 - 3 } & 300 & 271 \\
\cline { 2 - 3 } & 350 & 326 \\
\hline \multirow{4}{*}{550} & 250 & 206 \\
\cline { 2 - 3 } & 300 & 260 \\
\cline { 2 - 3 } & 350 & 315 \\
\hline
\end{tabular}

\subsection{Evaporation Process (Single droplet)}

In the test of evaporation time (single droplet), tested at temperatures of $250{ }^{\circ} \mathrm{C}, 300^{\circ} \mathrm{C}$, and $350^{\circ} \mathrm{C}$. The evaporation process of fuel on the heat plate is observed evaporation character and evaporation time for each fuel tested at each temperature. The evaporation time of the fuel, the temperature of the transition boiling regime and the appearance of fire are obtained from this process.
Table 4. Observation data on evaporation process.

\begin{tabular}{|c|c|c|c|c|c|c|}
\hline \multirow[b]{2}{*}{$\begin{array}{c}\text { Roo } \\
\text { m } \\
\text { Tem } \\
\text { pera } \\
\text { ture } \\
\left({ }^{\circ} \mathrm{C}\right)\end{array}$} & \multirow[b]{2}{*}{$\begin{array}{l}\text { Plate } \\
\text { Tem } \\
\text { pera } \\
\text { ture } \\
\left({ }^{\circ} \mathrm{C}\right)\end{array}$} & \multicolumn{5}{|c|}{ Variations of biodiesel } \\
\hline & & $\begin{array}{c}\text { B20 - } \\
\text { NA } \\
\text { (sec) }\end{array}$ & $\begin{array}{c}\text { B20+ } \\
\text { Essent } \\
\text { ial Oil } \\
1: 2000 \\
\text { (sec) }\end{array}$ & $\begin{array}{c}\text { B20 + } \\
\text { Essent } \\
\text { ial Oil } \\
1: 3000 \\
(\mathrm{sec}) \\
\end{array}$ & $\begin{array}{c}\text { B20 + } \\
\text { Essent } \\
\text { ial Oil } \\
1: 4000 \\
(\mathrm{sec})\end{array}$ & $\begin{array}{c}\text { B20 + } \\
\text { Essent } \\
\text { ial Oil } \\
1: 5000 \\
\text { (sec) }\end{array}$ \\
\hline \multirow{3}{*}{450} & 250 & 71 & 81.5 & 112.5 & 119.5 & 47 \\
\hline & 300 & 19.5 & 65 & 46.5 & 69.5 & 31 \\
\hline & 350 & 8.5 & 21 & 27 & 54 & 12.5 \\
\hline \multirow{3}{*}{450} & 250 & 40 & 44 & 45 & 58.5 & 16 \\
\hline & 300 & 16.5 & 33.5 & 20.5 & 35 & 2 \\
\hline & 350 & 16 & 22 & 10 & 7.5 & 1.33 \\
\hline \multirow{3}{*}{450} & 250 & 12 & 10.5 & 15 & 7.5 & 8.33 \\
\hline & 300 & 8 & 2.33 & 8 & 5.33 & 0.67 \\
\hline & 350 & 1 & 0 & 5 & 1 & 0 \\
\hline \multirow{4}{*}{$\begin{array}{c}\text { Expl } \\
\text { anati } \\
\text { on }\end{array}$} & \multicolumn{6}{|c|}{$\begin{array}{l}\text { Regular evaporate / nucleate boiling } \\
\text { regime }\end{array}$} \\
\hline & \multicolumn{6}{|c|}{ Broken / transition boiling regime } \\
\hline & \multicolumn{6}{|c|}{ A fire appeared / oxidation } \\
\hline & & \multicolumn{5}{|c|}{ Broken and a fire appeared / oxidation } \\
\hline
\end{tabular}

Fuel Evaporation Time in Room Temperature of $450{ }^{\circ} \mathrm{C}$

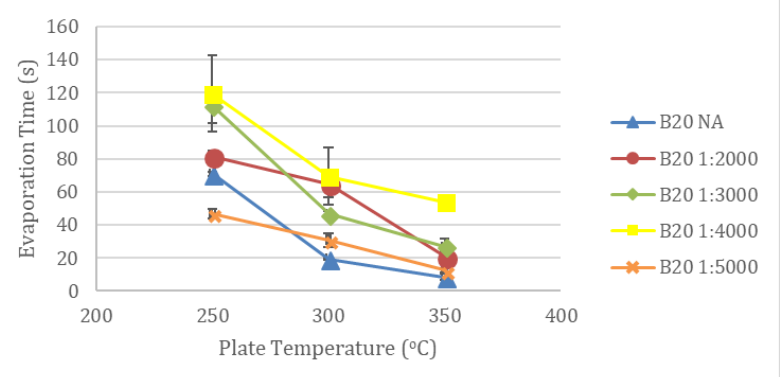

Fig. 2. Evaporation Time of Fuel at Room Temperature $450^{\circ} \mathrm{C}$.

Fuel Evaporation Time in Room Temperature of $500{ }^{\circ} \mathrm{C}$

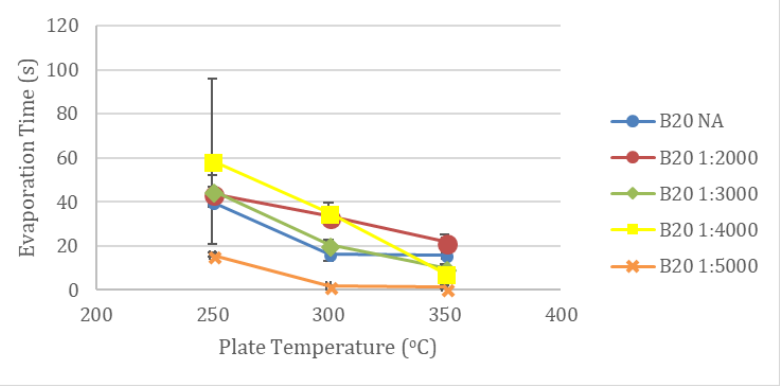

Fig. 3. Evaporation Time of Fuel at Room Temperature $500^{\circ} \mathrm{C}$. 


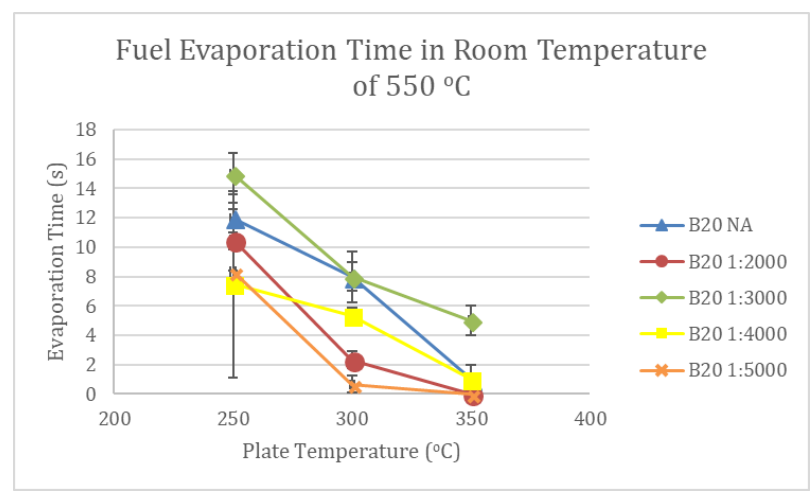

Fig. 4. Evaporation Time of Fuel at Room Temperature $550^{\circ} \mathrm{C}$.

The evaporation time affects the area of the deposit and the mass of the resulting deposit. Depositing deposits occur when the fuel has not evaporated completely and then the next droplet has fallen back on the hot plate. This condition is also called overlapping condition.

In Table 4, There are some information that can be observed from the observations on the data that have been obtained. For gray-colored cells is an evaporative phenomenon that occurs between the boiling point or IBT core point and the maximum evaporation point or MEP. Among the IBT points of this MEP fund, the evaporating phenomenon that occurs is evaporation occurs slowly after the droplet of fuel is dropped on the hot plate. Although it does not show a particular trend among comparisons of bioadditive concentrations added, the use of fuel with bioadditive additions to the smallest concentration, ie in the 1:5000 concentration, generally shows faster evaporation times than on other concentrations using both variations room temperature and hot plate temperature.

In table 4, also indicated there is a phenomenon in which droplets that fall on a hot plate experience a phenomenon such as rupture. In this phenomenon, the fuel is spherically evaporated or buckled like a ball and then evaporated in a very fast time. This phenomenon occurs in the transition boiling regime as shown in the illustration in Fig. under. In this transition boiling regime, there is a layer of vapor or vapor layer between the droplets that fall with the surface of the plate so that the observation of the phenomenon that occurred droplet is like not touching the surface of the plate and will roll to the edge of the plate. From the above observations, the phenomenon as in transition boiling regime occurs at room temperature $500^{\circ} \mathrm{C}$ and $550^{\circ} \mathrm{C}$ on additive usage which tends to have small concentrations also on the B20 fuel itself.

\subsection{Deposition Process (Multi droplet)}

The fuel deposition process on the hot plate produces the character and growth of the deposit at each temperature. The observable deposit character is the structure and contour of the deposit surface. Deposit growth can be obtained by measuring the mass of the deposit (the amount of the deposit). The results of the deposition process are as follows.

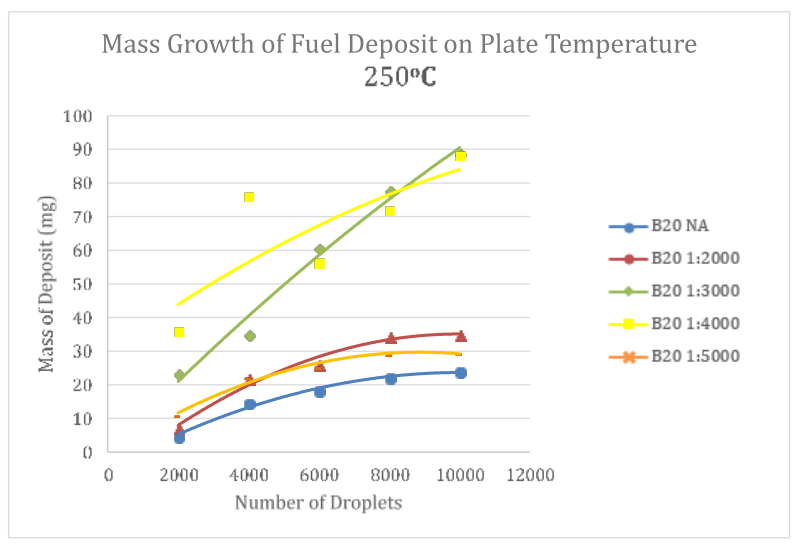

Fig. 5. Mass deposit on Plate Temperature $250^{\circ} \mathrm{C}$.

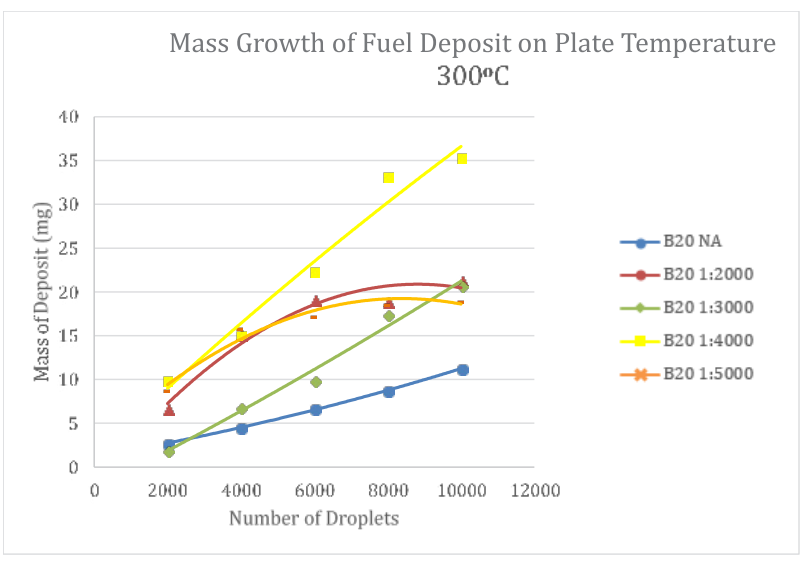

Fig. 6. Mass deposit on Plate Temperature $300^{\circ} \mathrm{C}$.

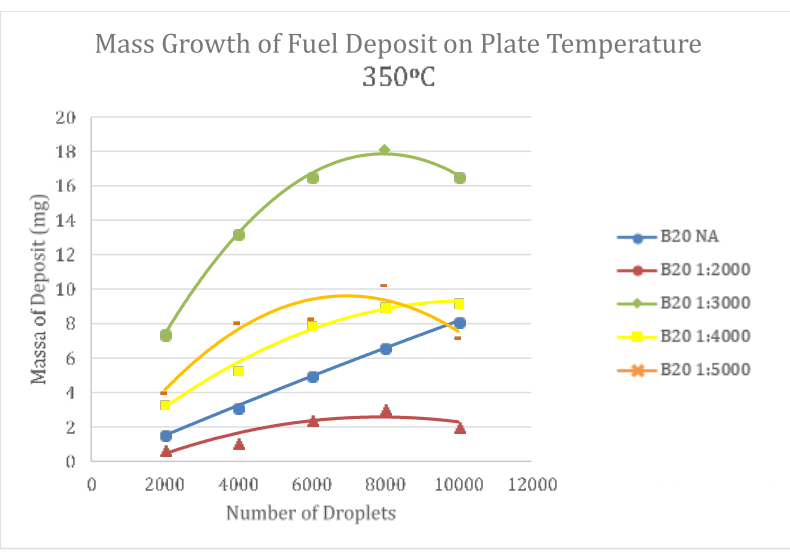

Fig. 7. Mass deposit on Plate Temperature $350^{\circ} \mathrm{C}$.

From the data on the amount of mass deposits that have been produced, it is concluded that the addition of composition bioadditive to biodiesel fuel can enlarge the potential for deformation of the deposit (early deformation process) when the composition of the mixture and also the ideal temperature conditions on the bioadditive of essential oil is achieved so that the fuel produced work optimally. The turpentine or oxygenate composition contained in the composition bioadditive 
also needs special studies to obtain the ideal bioadditive composition for biodiesel.

\section{Conclusion}

In this paper, forming of deposits from biodiesel with different variation, that are B20-NA, B20+Essential oil $1: 2000$, B20+Essential oil 1:3000, B20+Essential oil 1:4000, and B20+Essential oil 1:5000 will be observed with hot surface plate methode to find their characteristics and growth mechanisms of deposits from every biodiesel variation. The main conclusions are summarized as follows:

1. Based on the evaporative time table, B20 + Atsiri 1: 5000 becomes the most combustible fuel, this corresponds to a mass-deposit graph showing the fuel is deformed earlier.

2. $350{ }^{\circ} \mathrm{C}$ plate temperature is of particular concern because it shows the phenomenon of deposit deformation in some variations of fuel.

3. At 6000-8000 droplets a turning point occurs deformation in some test fuel.

4. The addition of volatile bioadditive to biodiesel fuel can enlarge the potential of deformation process early when mixed compositions as well as ideal temperature conditions on essential bioaditives are achieved so that the resulting fuel can work optimally.

The author would like to thanks to PITTA Grant 2018 (Contract no. 2392/UN2.R3.1/HKP.05.00/2018) from University of Indonesia as a funding research so that this research goes well, thanks to Mr. B. Sugiarto, as a mentor of this research, Mr. Hari Setiapraja, Mrs. Siti Yubaidah, as a team reasearchers from BT2MP, and to Mr. Mochammad Ilham Attharik, Mr. Muhamad Raihan Ariestiawan, Mr. Andro Cohen, and Mr. Ary Budi Mulyono as a team of researchers who participated in the research, so this research can be implemented well.

\section{References}

1. S.S. Wirawan and A.H. Tambunan, The current status and prospects of biodiesel development in Indonesia: A review, Presented on the Third Asia Biomass Workshop (2006)

2. A. Demirbas, Biofuels securing the planet's future energy needs, Energy Conversion and Management, 50.9, 2239-2249 (2009)

3. S.R Bull, Renewable energy transportation technologies, Renewable Energy, 9, 1019-1024 (1996)

4. A. Liaquat, et al, Impact of palm biodiesel blend on injector deposit formation, Applied energy, 111: p. 882-893 (2013)

5. T. Omori, et al., Biodiesel deposit formation mechanism and improvement of Fuel Injection Equipment (FIE), SAE Technical Paper (2011)
6. J. Bouilly, et al., Biodiesel stability and its effects on diesel fuel injection equipment, SAE Technical Paper (2012)

7. Y.S. Lin and H.P. Lin, Spray characteristics of emulsified castor biodiesel on engine emissions and deposit formation, Renewable energy, 36(12): p. 3507-3516 (2011)

8. Y.M. Arifin, Diesel and Bio-diesel Fuel Deposits on a Hot wall Surface (2009)

9. M.T. Suryantoro, B. Sugiarto, and F. Mulyadi. Growth and characterization of deposits in the combustion chamber of a diesel engine fueled with B50 and Indonesian biodiesel fuel (IBF), Biofuel Research Journal, 3(4): p. 521-527, (2016)

10. B. Sugiarto, et al., The effect of antioxidant additives on the growth of deposits on the use of biodiesel fuel (B100) at certain temperatures, IOP Conference Series: Earth and Environmental Science. Vol. 105. No. 1. IOP Publishing, (2018)

11. M.T. Suryantoro, B. Sugiarto, D. Chistian, B. Samudra, Z. Gusfa, Deposit Characterization of a Diesel Engine Combustion Chamber by Droplets at Hot Chamber Temperature: Effect of Temperature on Evaporation Time and Deposit Structure, International Journal of Technology 7 1372-80 (2016) 